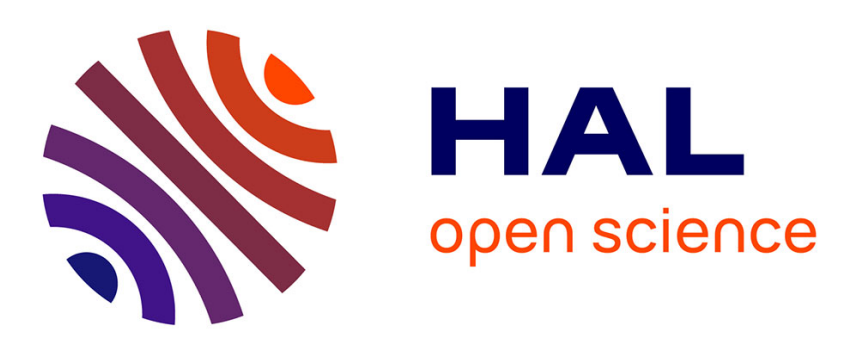

\title{
Drought sensitivity of Norway spruce is higher than that of silver fir along an altitudinal gradient in southwestern Germany
}

\author{
Marieke Maaten-Theunissen, Hans-Peter Kahle, Ernst Maaten
}

\section{- To cite this version:}

Marieke Maaten-Theunissen, Hans-Peter Kahle, Ernst Maaten. Drought sensitivity of Norway spruce is higher than that of silver fir along an altitudinal gradient in southwestern Germany. Annals of Forest Science, 2013, 70 (2), pp.185-193. 10.1007/s13595-012-0241-0 . hal-01201461

\author{
HAL Id: hal-01201461 \\ https://hal.science/hal-01201461
}

Submitted on 17 Sep 2015

HAL is a multi-disciplinary open access archive for the deposit and dissemination of scientific research documents, whether they are published or not. The documents may come from teaching and research institutions in France or abroad, or from public or private research centers.
L'archive ouverte pluridisciplinaire HAL, est destinée au dépôt et à la diffusion de documents scientifiques de niveau recherche, publiés ou non, émanant des établissements d'enseignement et de recherche français ou étrangers, des laboratoires publics ou privés. 


\title{
Drought sensitivity of Norway spruce is higher than that of silver fir along an altitudinal gradient in southwestern Germany
}

\author{
Marieke van der Maaten-Theunissen • Hans-Peter Kahle • \\ Ernst van der Maaten
}

Received: 17 July 2012 / Accepted: 23 August 2012 /Published online: 14 September 2012

(C) INRA / Springer-Verlag France 2012

\begin{abstract}
- Context For Central Europe, climate projections foresee an increase in temperature combined with decreasing summer precipitation, resulting in drier conditions during the growing season. This might negatively affect forest growth, especially at sites that are already water-limited, i.e., at low elevation. At higher altitudes trees might profit from increasing temperatures.

- Aims We analyzed variations in radial growth of silver fir (Abies alba Mill.) and Norway spruce (Picea abies (L.) Karst.) along an altitudinal gradient from 400 until 1,140 $\mathrm{m}$ a.s.l. in the Black Forest, to assess climate responses with increasing elevation.

- Methods Climate-growth relationships were analyzed retrospectively using tree-ring and climate data. In total, we sampled stem discs of 135 trees to build 27 species- and site-specific chronologies $\left(n_{\text {fir }}=13, n_{\text {spruce }}=14\right)$.

- Results Our results indicate distinct differences in climategrowth relations between fir and spruce along the gradient. Growth of high-altitude fir was positively related to temperature from January till March. Growth of low-altitude fir and
\end{abstract}

Handling Editor: Erwin Dreyer

Electronic supplementary material The online version of this article (doi:10.1007/s13595-012-0241-0) contains supplementary material, which is available to authorized users.

Contribution of the co-authors Marieke van der Maaten-Theunissen designed the study and collected all tree-ring data, except for five chronologies originating from work by Hans-Peter Kahle. She analyzed the data and was supported in writing the manuscript by Ernst van der Maaten and Hans-Peter Kahle.

M. van der Maaten-Theunissen $(\varangle) \cdot$ H.-P. Kahle •

E. van der Maaten

Institute for Forest Growth, Albert-Ludwigs-University Freiburg,

Tennenbacher Str. 4,

79106 Freiburg, Germany

e-mail: marieketheunissen@gmail.com spruce at all elevations was positively related to precipitation and negatively to temperature during the growing season, particularly in July. A self-calibrating Palmer drought severity index underlined summer drought sensitivity of these trees.

- Conclusion Overall, we found that climatic control of tree growth changes over altitude for fir. For spruce, a remarkable synchrony in growth variation and climate response was shown, which indicates that this species is drought sensitive at all studied elevations. In a future warmer climate, the growth of low-altitude fir and spruce along the entire studied gradient may be negatively affected in the Black Forest, if an increased evaporative demand cannot be compensated by increased water supply.

Keywords Tree rings · Dendrochronology $\cdot$ Climate-growth relationships

\section{Introduction}

For Central Europe, increases in annual air temperature up to $4^{\circ} \mathrm{C}$ by the end of this century are predicted under climate change, whereby extremely high summer temperatures are expected to increase even more than average summer temperatures (Christensen et al. 2007). As the amount of precipitation in summer is likely to decrease as well (Maracchi et al. 2005), drought events will occur more frequently during the growing season. This might have negative consequences for tree growth and vitality. Major reductions in the productivity of European forests were already observed under the extremely warm and dry climate anomaly in 2003 (Ciais et al. 2005). However, some trees may also benefit from a warmer climate, e.g. at higher elevations, as these sites are primarily temperature-limited (Körner and Paulsen 2004; Tranquillini 1979). In the Swiss Alps, Jolly et al. (2005) analyzed both satellite-derived photosynthetic 
activity estimates and in situ forest growth measurements for 2003 and found growth enhancements at high elevations, while trees at low elevations suffered from drought. Similar altitudinal differences in growth responses to extremely warm and dry climate conditions have been found in the Swiss Lötschental (Neuwirth et al. 2004), Swiss Valais (Lingg 1986) and French Alps (Desplanque et al. 1999).

Studies on climate-growth relationships along ecological gradients have shown that differences in growth responses between species are important to consider (e.g. Affolter et al. 2010; Graumlich 1993; Scharnweber et al. 2011). By comparing ten coniferous species along altitudinal gradients in four different climatic regions, Kienast et al. (1987) found consistent tendencies in ring width and maximum density relating to altitude, although climate-growth relationships showed considerable variation between sites and species at the same altitudinal level.

In this study, we analyzed radial growth of silver fir (Abies alba Mill.) and Norway spruce (Picea abies (L.) Karst.) along an altitudinal gradient in the Black Forest, southwestern Germany. Both species are highly abundant and economically important in this region. Previous studies on fir and spruce, e.g. in the French Alps, revealed a drought sensitivity of both species at low elevation and southern exposed sites (Desplanque et al. 1999; Rolland et al. 2000). Further, Lebourgeois (2007) and Rolland et al. (1999) found that water supply in the previous year mainly influences current-year growth of fir, whereas for spruce, both previous and current summer precipitation and temperature were of major importance (Bouriaud and Popa 2009). At high elevation, cold temperatures in winter and early spring were found to negatively affect growth of both tree species (Desplanque et al. 1999; Rolland et al. 2000), but fir was more sensitive to late frost and extremely low winter temperatures than spruce (Bouriaud and Popa 2009; Frank and Esper 2005; Gerecke 1986; Lebourgeois 2007; Lebourgeois et al. 2010).

By comparing growth responses of silver fir and Norway spruce along an altitudinal gradient, this study aims at increasing the understanding on altitude- and species-specific effects of climatic factors on growth, which is necessary to assess the responses of tree growth to anticipated climate changes. Trees were sampled at southwest-exposed slopes of the Black Forest, as climatic conditions are more extreme here, with higher wind load and incident radiation.

\section{Material and methods}

\subsection{Study area and site selection}

The study area is located in the Black Forest, southwestern Germany $\left(47^{\circ} 42^{\prime}-48^{\circ} 06^{\prime} \mathrm{N}, 7^{\circ} 40^{\prime}-8^{\circ} 00^{\prime} \mathrm{E}\right)$. Elevations range between ca. $300 \mathrm{~m}$ till almost $1,500 \mathrm{~m}$ a.s.l. The actual upper treeline in the Black Forest is at about 1,400 $\mathrm{m}$ a.s.l., whereas the forest line, where trees form closed-canopy forest, is at around 1,200 $\mathrm{m}$ a.s.l. Along the gradient, natural forest types gradually change from submontane beech-oakfir forest, to montane beech-fir forest mixed with pine, to high-montane fir-spruce forest. Without human interventions, the share of Norway spruce would be small and restricted to the high-mountainous zones (Schlenker and Müller 1978).

Study sites were selected in a two-step procedure that aimed at establishing a dataset typical for southwest-exposed closedcanopy fir and spruce stands along an altitudinal gradient. First, we made a pre-selection in ArcGis Desktop10 based on digital forest classification and forest site data that were provided by the Regierungspräsidium Freiburg and Forest Research Institute of Baden-Württemberg, respectively. A final selection of 19 sites was made after field verification and was based on altitude, exposition and similarity in stand structure. In addition, data from five sites from a former research project were included (Table 1).

The predominant soil type is cambisol and the available soil water capacity (AWC) ranges from very low $(<50 \mathrm{~mm})$ to medium (90-140 mm) at the different sites (Table 1).

\subsection{Climate data}

Site-specific climate data was obtained from spatially interpolated gridded data $(1 \mathrm{~km} \times 1 \mathrm{~km})$ derived from the network of meteorological measurement stations of the German Weather Service, which is available from the web-based weather request and distribution system WebWerdis (http://www.dwd.de/ webwerdis). Monthly temperature and precipitation data were extracted for the period 1950-2009. Distinct differences in baseline climate exist among the sites, as mean annual air temperature decreases and annual precipitation increases with elevation (Fig. 1). A warming trend can be observed for mean annual air temperature since the $1980 \mathrm{~s}$, whereas no trend is visible in the annual precipitation sum (Fig. 2).

For each site, a self-calibrating Palmer drought severity index (sc-PDSI) was calculated using an online available tool from the GreenLeaf project (available at: http://greenleaf. unl.edu) to test the combined effect of temperature and precipitation in terms of water availability on tree growth. The sc-PDSI is a variant of the original drought index by Palmer (PDSI) (1965) and improves upon PDSI by automatically calibrating climatic characteristics and duration factors based on historic climate data, making spatial comparisons more meaningful (Wells et al. 2004). Required input variables for the calculation are monthly temperature and precipitation, latitude and AWC. Values normally range between -4 (extreme drought) and +4 (extremely wet), while values near zero indicate average soil moisture conditions (Palmer 1965). 
Table 1 Site description and characteristics of sample trees (in order of increasing altitude)

\begin{tabular}{|c|c|c|c|c|c|c|c|c|c|c|}
\hline Site & Site $\mathrm{nr}$ & $\begin{array}{l}\text { Altitude } \\
\text { (m a.s.l) }\end{array}$ & No. of trees & $\begin{array}{c}\text { Time span } \\
\text { (all trees) }\end{array}$ & Age (years) & $\mathrm{DBH}(\mathrm{cm})$ & Tree height (m) & Aspect & Slope (\%) & AWC \\
\hline \multicolumn{11}{|l|}{ Silver fir } \\
\hline MUGG & 1 & 400 & 5 & 1924-2010 & $103.2(10.2)$ & $59.1(4.5)$ & $29.1(1.6)$ & SW & 59 & 2,3 \\
\hline BRIT & 2 & 430 & 5 & 1954-2009 & $75.8(13.3)$ & $53.6(6.1)$ & $30.4(1.7)$ & SSW & 36 & 2,3 \\
\hline WALDF & $3 a$ & 430 & 5 & $1910-2010$ & $109.8(10.0)$ & $70.0(5.6)$ & $30.9(1.5)$ & SW & 62 & 2,3 \\
\hline STAU & 4 & 430 & 5 & $1906-2010$ & $123.6(18.7)$ & $51.7(2.4)$ & $27.0(1.5)$ & WSW & 38 & 1,2 \\
\hline SULZ & 5 & 450 & 5 & 1937-2009 & $84.0(7.0)$ & $66.8(7.8)$ & $33.3(2.7)$ & SSW & 37 & 2,3 \\
\hline $\mathrm{AU}$ & 6 & 520 & 5 & 1971-2010 & $42.8(3.6)$ & $43.5(5.0)$ & $25.2(1.4)$ & WSW & 43 & 2,3 \\
\hline BURG & 7 & 650 & 5 & 1909-2009 & $103.4(2.1)$ & $58.7(4.5)$ & $31.3(2.5)$ & W & 65 & 1,2 \\
\hline ADELF & $8 \mathrm{a}$ & 750 & 5 & 1920-2010 & $93.2(2.2)$ & $66.9(7.9)$ & $35.0(1.8)$ & $\mathrm{S}$ & 41 & 1,2 \\
\hline NEUE & 9 & 800 & 5 & 1945-2010 & $71.0(6.5)$ & $57.9(3.5)$ & $31.9(2.8)$ & $\mathrm{S}$ & 67 & 1,2 \\
\hline EGER & 10 & 920 & 5 & 1973-2009 & $43.0(4.5)$ & $44.8(2.2)$ & $24.0(3.6)$ & $\mathrm{S}$ & 62 & 1,2 \\
\hline KUHLF & $11 \mathrm{a}$ & 970 & 4 & 1913-2010 & $100.8(3.2)$ & $66.7(9.7)$ & $28.4(1.9)$ & WSW & 35 & 1,2 \\
\hline FISC & 12 & 985 & 5 & 1917-2010 & $96.6(1.7)$ & $60.4(3.8)$ & $27.7(0.4)$ & WSW & 28 & 2,3 \\
\hline KOHL & 13 & 1050 & 4 & 1921-2010 & $107.3(17.1)$ & $68.4(9.1)$ & $27.6(1.8)$ & SW & 70 & 2,3 \\
\hline \multicolumn{11}{|c|}{ Norway spruce } \\
\hline WALDS & $3 b$ & 430 & 5 & 1931-2010 & $86.2(7.3)$ & $55.1(2.4)$ & $32.3(0.6)$ & SW & 61 & 2,3 \\
\hline EHRE & 14 & 470 & 5 & 1948-2006 & $62.2(2.4)$ & $31.3(1.2)$ & $27.4(2.2)$ & WSW & 57 & 2,3 \\
\hline GUNT & 15 & 500 & 5 & 1949-2009 & $62.4(1.1)$ & $52.3(1.1)$ & $30.8(2.1)$ & SSW & 64 & 2,3 \\
\hline KLOS & 16 & 530 & 5 & 1964-2010 & $49.6(2.1)$ & $43.4(3.3)$ & $27.8(1.5)$ & SSW & 71 & 1,2 \\
\hline MUNS & 17 & 640 & 5 & 1910-2009 & $102.2(2.8)$ & $48.2(6.6)$ & $29.8(1.8)$ & SSW & 74 & 2 \\
\hline DOTT & 18 & 690 & 5 & 1948-2006 & $62.8(4.1)$ & $30.0(0.6)$ & $24.4(2.0)$ & SW & 62 & 1,2 \\
\hline ADELS & $8 \mathrm{~b}$ & 750 & 5 & $1940-2010$ & $71.8(0.8)$ & $58.7(5.4)$ & $31.9(6.4)$ & $\mathrm{S}$ & 55 & 1,2 \\
\hline MUNT & 19 & 780 & 5 & 1920-2006 & $89.2(1.5)$ & $53.1(0.4)$ & $35.6(2.3)$ & SSW & 56 & 2 \\
\hline BLAU & 20 & 960 & 5 & 1971-2009 & $47.4(5.0)$ & $41.6(5.3)$ & $27.2(2.7)$ & $\mathrm{S}$ & 39 & 1,2 \\
\hline KUHLS & $11 \mathrm{~b}$ & 970 & 5 & 1903-2010 & $112.4(3.5)$ & $53.3(9.6)$ & $28.9(2.6)$ & WSW & 41 & 1,2 \\
\hline AFTE & 21 & 1027 & 5 & 1966-2006 & $46.6(3.4)$ & $29.3(1.4)$ & $22.3(0.6)$ & WSW & 55 & 1,2 \\
\hline BERN & 22 & 1030 & 5 & 1966-2010 & $48.4(4.4)$ & $37.7(2.8)$ & $22.1(0.5)$ & $\mathrm{S}$ & 62 & 2,3 \\
\hline SIRN & 23 & 1040 & 5 & $1921-2010$ & $94.6(4.2)$ & $54.4(2.8)$ & $28.5(0.7)$ & SW & 82 & 2,3 \\
\hline TODT & 24 & 1140 & 5 & 1902-2006 & $118.6(15.3)$ & $46.5(7.6)$ & $24.5(2.8)$ & WSW & 52 & 2,3 \\
\hline
\end{tabular}

At site WALD, ADEL and KUHL both fir and spruce were collected, as indicated by the suffixes F and S, respectively. Age refers to age at breast height, $D B H$ diameter at breast height, Aspect exposition of study site: $S$ south, $W$ west, $A W C$ available soil water capacity: 1 very low ( $<50$ mm), 2 low $(50-90 \mathrm{~mm}), 3$ medium $(90-140 \mathrm{~mm})$. Values are means with standard deviations in parentheses

\subsection{Tree-ring data}

Per site, we collected stem discs at breast height of five dominant or co-dominant fir or spruce trees from the stand interior with no visible signs of damage. On three sites, we sampled both fir and spruce trees. Stem discs were air-dried and sanded to highlight ring boundaries. Annual radial growth was measured in eight pre-defined directions using semi-automatic image analysis software (developed at the Institute for Forest Growth). For each tree, the annual radial growth was calculated as the quadratic mean of the eight measurements. The tree-ring series were cross-dated visually and tested statistically (Gleichläufigkeit). Each series was detrended by fitting a cubic smoothing spline with 50\% frequency cut-off at 30 years, in order to remove long-term trends and to retain high-frequency variability (Cook and
Peters 1981), using MATLAB's (V7.9.0, R2009b) Spline Toolbox function csaps (V3.3.7) in combination with the spline smoothing parameter function splinep (presented courtesy of J.L. Dupouey). Indices were calculated dividing the observed by the predicted values. Chronologies were constructed per site and tree species (in total 27 chronologies), and inter-series correlations (IC), mean sensitivities (MS) and first-order autocorrelations (AC) were calculated over the common overlap period 1974-2006. The IC is the average correlation coefficient between the series, MS is the average relative difference in radial increment between consecutive years and $\mathrm{AC}$ assesses the average relation between subsequent values within the time series (Fritts 1976). The confidence of the chronologies was evaluated by the expressed population signal (EPS), which indicates the degree to which the particular sample chronology portrays a 

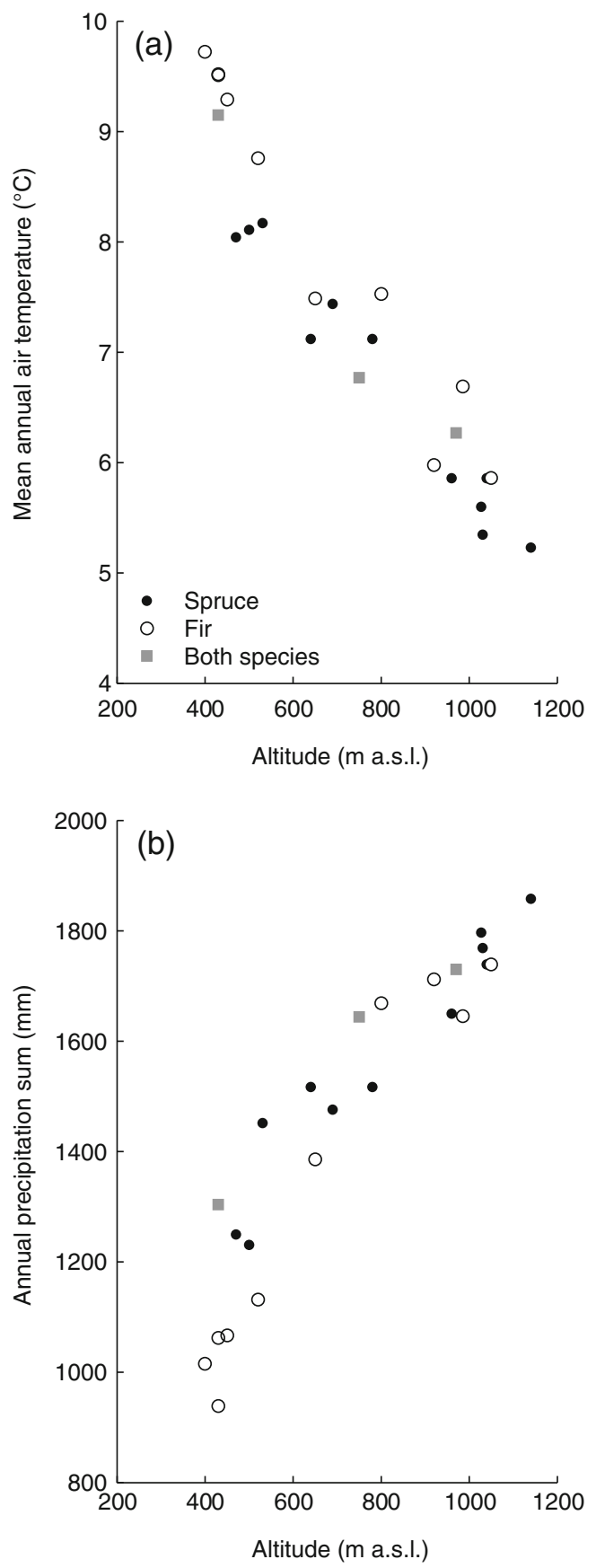

Fig. 1 (a) Mean annual air temperature and (b) total annual precipitation at the study sites during the climate normal period 1961-1990 versus altitude

hypothetically perfect chronology (Wigley et al. 1984). EPS values were calculated with the wigleyl function (presented courtesy of D. Meko). All computations were carried out using MATLAB (V7.9.0, R2009b).

\subsection{Statistical analysis}

We calculated Pearson correlation coefficients between site chronologies and plotted them as a function of altitudinal
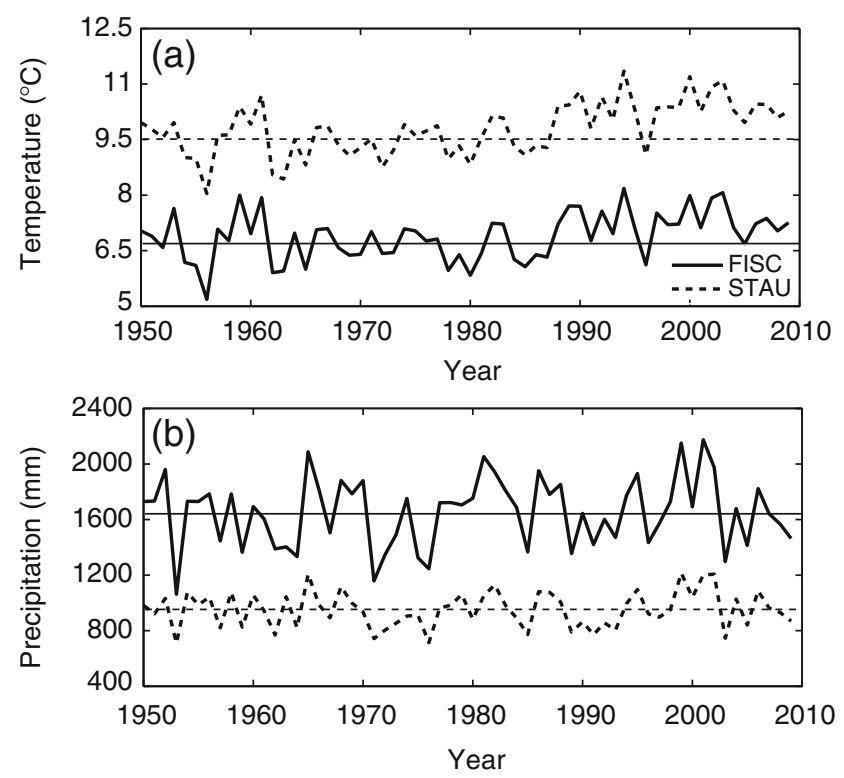

Fig. 2 Time series of a mean annual air temperature and $\mathbf{b}$ total annual precipitation of a high-altitude site (FISC) and a low-altitude site (STAU) for the period 1950-2009, horizontal lines denote average values of the climate normal period 1961-1990

distance, to analyze whether sites at the same altitude have more growth variation in common compared to sites that are further apart. Principal component analysis (PCA) was performed to investigate common growth signals in the site chronologies. Principal component scores represent the common growth variation, whereas the component loadings indicate the association of chronologies with the component.

Climate factors mainly responsible for the variation in annual radial increment were determined by bootstrapped correlation analysis. Coefficients were calculated between site chronologies and monthly climate data for the period 1974-2006 using the software package DENDROCLIM2002 (Biondi and Waikul 2004). Monthly temperature, precipitation and sc-PDSI data over a 15 -month window were considered, from June of the previous year to August of the current year. In addition, seasonal temperature means and precipitation sums of April-August, MayAugust and June-August of the current year were included, hereafter referred to as season I, II and III.

\section{Results}

\subsection{Chronology characteristics and growth variations}

For the period 1974-2006, the IC of the sites varies from 0.593 to 0.887 (Table 2), indicating strong common signals between trees from the same site. For both species, sites at lower altitudes have the largest MS values, suggesting a higher climate-sensitivity of these trees. All chronologies 
Table 2 Chronology statistics of tree-ring series (in order of increasing altitude)

\begin{tabular}{|c|c|c|c|c|c|}
\hline Site & RI (SD) & IC & MS & $\mathrm{AC}$ & EPS \\
\hline \multicolumn{6}{|l|}{ Silver fir } \\
\hline MUGG & $3.57(1.78)$ & 0.729 & 0.294 & 0.298 & 0.931 \\
\hline BRIT & $4.17(1.46)$ & 0.883 & 0.198 & 0.406 & 0.974 \\
\hline WALDF & $4.02(1.67)$ & 0.696 & 0.256 & 0.150 & 0.920 \\
\hline STAU & $2.67(1.19)$ & 0.838 & 0.290 & 0.272 & 0.963 \\
\hline SULZ & $4.99(1.86)$ & 0.654 & 0.227 & 0.227 & 0.905 \\
\hline $\mathrm{AU}$ & $4.91(1.21)$ & 0.764 & 0.224 & -0.115 & 0.942 \\
\hline BURG & $3.14(1.10)$ & 0.690 & 0.221 & -0.024 & 0.917 \\
\hline ADELF & $3.79(1.14)$ & 0.670 & 0.159 & 0.187 & 0.910 \\
\hline NEUE & $4.36(1.01)$ & 0.672 & 0.156 & 0.209 & 0.911 \\
\hline EGER & $5.05(1.09)$ & 0.627 & 0.155 & 0.328 & 0.894 \\
\hline KUHLF & $3.55(0.87)$ & 0.633 & 0.145 & 0.290 & 0.873 \\
\hline FISC & $3.22(1.37)$ & 0.692 & 0.156 & 0.523 & 0.918 \\
\hline $\mathrm{KOHL}$ & $2.93(1.42)$ & 0.593 & 0.185 & 0.483 & 0.854 \\
\hline \multicolumn{6}{|c|}{ Norway spruce } \\
\hline WALDS & $3.16(1.16)$ & 0.775 & 0.235 & 0.215 & 0.945 \\
\hline EHRE & $1.92(0.58)$ & 0.786 & 0.200 & 0.328 & 0.948 \\
\hline GUNT & $3.97(1.31)$ & 0.666 & 0.200 & 0.376 & 0.909 \\
\hline KLOS & $3.66(1.01)$ & 0.688 & 0.193 & 0.270 & 0.917 \\
\hline MUNS & $2.17(0.69)$ & 0.887 & 0.184 & 0.521 & 0.975 \\
\hline DOTT & $1.93(0.56)$ & 0.595 & 0.193 & 0.266 & 0.880 \\
\hline ADELS & $3.30(0.89)$ & 0.685 & 0.192 & 0.356 & 0.916 \\
\hline MUNT & $2.17(0.69)$ & 0.790 & 0.229 & 0.311 & 0.950 \\
\hline BLAU & $3.85(0.99)$ & 0.816 & 0.201 & 0.363 & 0.957 \\
\hline KUHLS & $2.48(0.63)$ & 0.726 & 0.185 & 0.231 & 0.930 \\
\hline AFTE & $2.75(0.70)$ & 0.761 & 0.120 & 0.426 & 0.941 \\
\hline BERN & $3.52(1.28)$ & 0.836 & 0.157 & 0.572 & 0.962 \\
\hline SIRN & $2.54(0.55)$ & 0.788 & 0.164 & 0.322 & 0.949 \\
\hline TODT & $1.77(0.65)$ & 0.884 & 0.193 & 0.582 & 0.974 \\
\hline
\end{tabular}

Statistics refer to the maximum common overlap period 1974-2006

$R I$ radial growth (mm) with standard deviation (SD), $I C$ inter-series correlation, $M S$ mean sensitivity, $A C$ first-order autocorrelation, $E P S$ expressed population signal

show EPS values exceeding the threshold of 0.85 as proposed by Wigley et al. (1984), meaning that the chronologies can be considered representative for tree growth at the sites.

Pearson correlation coefficients between site chronologies were plotted as a function of distance in altitude between sites (Fig. 3). For silver fir, the strength of the correlation significantly decreases with increasing distance, whereas the correlation coefficients for Norway spruce are higher and decrease only slightly with increasing altitudinal distance.

To reveal common patterns in the 27 site chronologies a PCA was performed. Three low-altitude fir sites (STAU, BRIT, MUGG) and the spruce sites have the highest loadings on the first principal component (PC1), which explains $55.6 \%$ of the total variance (Fig. 4a). The scores of $\mathrm{PC} 1$ show the common

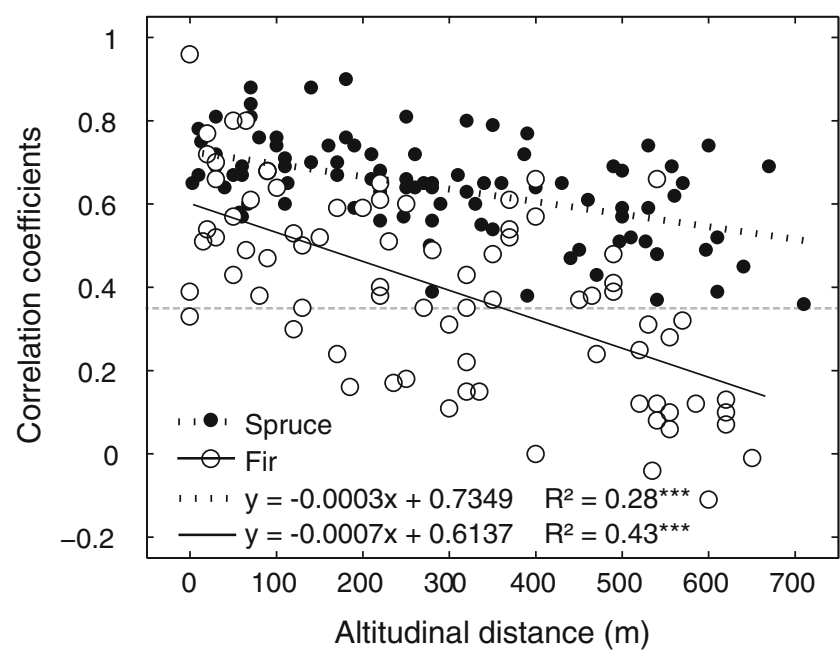

Fig. 3 Pearson correlation coefficients between site chronologies as a function of altitudinal distance. The horizontal dotted line denotes the 95\% confidence limit. Asterisks indicate significance levels of linear regressions, $* * * P<0.001$

growth variation of the chronologies, with pronounced growth depressions in the dry years 1976, 2003 and 2006 (Fig. 4b).

\subsection{Climate-growth relationships}

Bootstrapped correlation analyses between site chronologies of fir (Fig. S1) and spruce (Fig. S2) and monthly temperature,
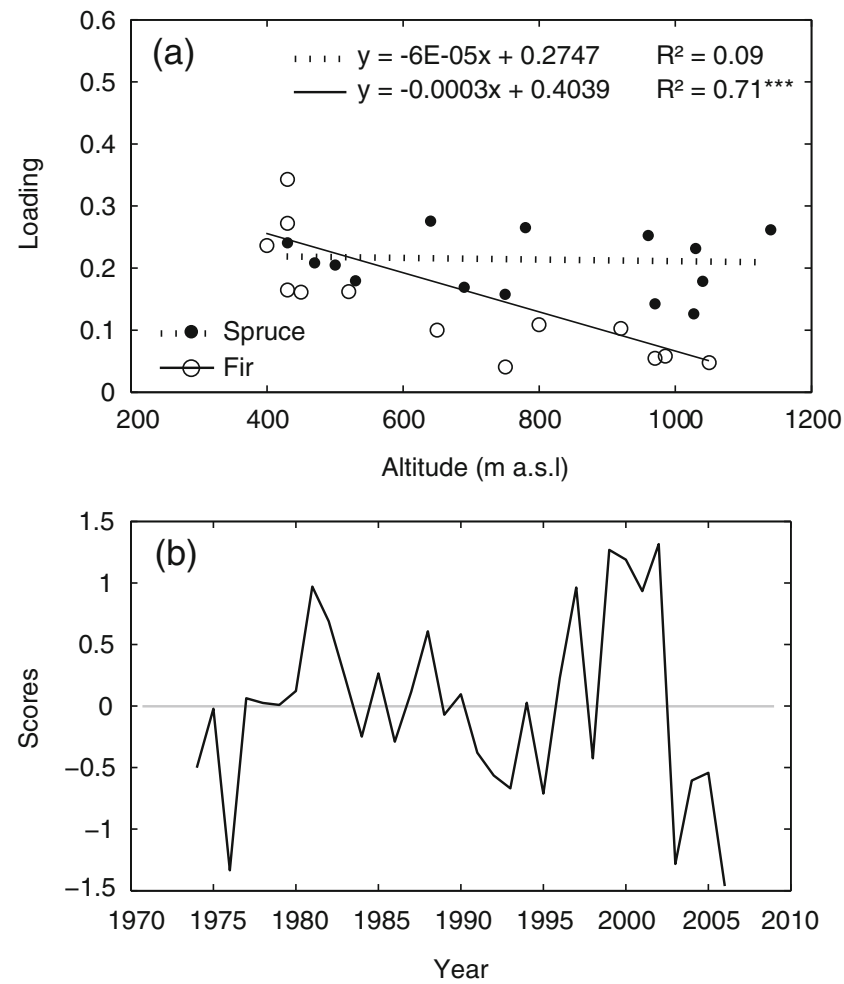

Fig. 4 a Loadings and $\mathbf{b}$ scores of the first principal component of the 27 site chronologies. PC1 explains $55.6 \%$ of the total variance. Lines indicate linear regressions 
precipitation and sc-PDSI revealed altitude- and speciesspecific differences in climate-growth relationships.

Growth of fir at sites above $900 \mathrm{~m}$ a.s.l. is reduced under low temperatures from January till March, as indicated by significant positive correlations with temperature in these months (Fig. S1). For the highest site, also seasonal temperatures (I, II, III) are found to have a positive effect on growth, whereas at lower elevations radial growth is negatively related to temperature and positively to precipitation during the growing season. For low-altitude sites, significant correlations with sc-PDSI assume a high drought sensitivity of these trees. Further, a positive correlation with precipitation in February, suggests a favorable effect on water availability at the subsequent beginning of the growing season. However, a positive effect of temperature (cf. high-altitude sites) may be suggested as well, as high precipitation amounts in winter as usually accompanied by relatively high temperatures (low-pressure area).

Similar to high-altitude fir, high-altitude spruce shows significant positive correlations with March temperature at higher elevations (Fig. S2). Over the entire altitudinal range, negative correlations with previous and current-year July temperatures are found, indicating that growth of spruce is negatively affected by high summer temperatures independent of altitude. Strong positive correlations with current-year June and July precipitation as well as with seasonal precipitation (I, II, III), however, suggest that especially low-altitude spruce suffers under summer drought. This is substantiated by the strong correlations with sc-PDSI for these trees. But, also at higher elevations spruce seems still sensitive to drought, as illustrated by correlation coefficients for sc-PDSI in July plotted over altitude (Fig. 5). Although the strength of the

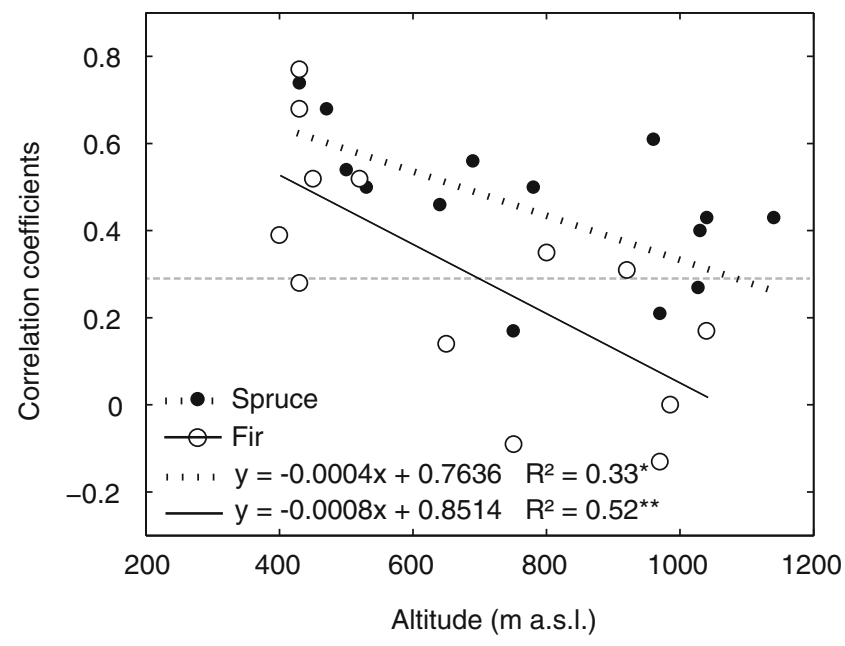

Fig. 5 Bootstrapped correlation coefficients between standardized chronologies of spruce and fir and sc-PDSI in July as a function of altitude. The horizontal dotted line denotes the $95 \%$ confidence limit. Asterisks indicate significance levels of linear regressions, ${ }^{*} P<0.05$, $* * P<0.01$ correlations decreases with altitude for both species, they are generally higher for spruce than for fir, indicating higher summer drought sensitivity for spruce over the whole altitudinal range. Further, for fir, a switch between more precipitation-controlled growth towards more temperaturecontrolled growth can be observed around $800-900 \mathrm{~m}$ a.s.l.

\section{Discussion}

Our aim was to provide insight into climate factors controlling radial growth of silver fir and Norway spruce along an altitudinal gradient in southwestern Germany. We constructed 27 chronologies by measuring radial growth from stem discs of five dominant or co-dominant trees per site. The number of sampled trees contrasts with, e.g. Mérian and Lebourgeois (2011), who suggested using a total number of 15-20 trees per stand. However, as radial growth of our trees was measured on stem discs in eight pre-defined directions, radial growth estimates resulted from more detailed measurements than estimates of ring width based on only one core per tree (cf. van der Maaten-Theunissen and Bouriaud 2012). The reliability of the obtained site chronologies is substantiated by high inter-series correlations and high EPS values (Table 2) that are well above the critical threshold.

The analyzed tree-ring dataset contains variation in stand age among the study sites (Table 1). Although tree age might influence growth responses of trees to climate (cf. Carrer and Urbinati 2004; Szeicz and MacDonald 1994), a limited number of relatively young stands that met our selection criteria (see "Material and methods" section) hampered a separate analysis of trees belonging to different age classes. Hence, we analyzed climate-growth relationships for each study site individually (Figs. S1 and S2). The number of annual rings of the youngest trees restricted the common overlap period for these analyses to 33 years, but we were nevertheless able to identify major climatic constraints. As both younger and older stands displayed similarly directed climate responses over the altitudinal gradient, it is suggested that the identified climate limitations with altitude are of major importance for the area.

For spruce, our results indicate a high similarity in growth responses along the altitudinal gradient (Figs. 3 and 4). Similar to our study, Meining et al. (2004) observed reduced stem growth of Norway spruce in the extreme year 2003 at ten permanent monitoring plots in southwestern Germany (from $510 \mathrm{~m}$ to $1,020 \mathrm{~m}$ a.s.1.), irrespective of elevation (cf. scores of PC1 in Fig. 4b). Other studies found that fir and spruce from different altitudes share less variation in growth (Lingg 1986; Wilson and Hopfmüller 2001), but an effect of altitude was strongest for fir in our study (Fig. 3). Generally, stronger correlation coefficients between chronologies of spruce might relate to a stronger climate 
signal captured by this species. We could elucidate altitudedependent and species-specific growth patterns with results from the bootstrapped correlation analysis.

For growth of spruce, we observed strong correlations with both previous- and current-year climate conditions (Fig. S2). Of the previous-year conditions, negative effects of July temperature were strongest and present for almost all sites along the altitudinal gradient. The existence of such lagged climate effects on growth of spruce are known (e.g. Kahle 1996), and might be related to reduced growth rate and increased respiration losses under high temperatures that reduce the amount of carbohydrate reserves available for needle expansion and growth initiation at the beginning of the next growing season (Bouriaud and Popa 2009).

During the current season, both high temperatures and low precipitation amounts in summer were found to constrain growth of spruce (Fig. S2). This was substantiated by results for sc-PDSI. Although the strength of the correlation between growth and sc-PDSI decreased with altitude, spruce at high elevation was still found susceptible for waterlimitation (Figs. S2 and 5). This was unexpected because of the relatively high amounts of precipitation at these sites, but consistent with other studies in the same region (e.g. Kahle 1994; Spiecker 1991a) and in other mountainous regions like in Saxony, eastern Germany (Neumann and Röhle 2001).

Low-altitude fir sites displayed a negative correlation with temperature and a positive correlation with precipitation in current June/July (Fig. S1). Together with the high correlations with sc-PDSI for these months (Figs. S1 and 5), it indicates water availability in mid-summer as a major factor constraining growth of these trees. The importance of water availability for tree growth at low elevations is supported by previous studies (e.g. Affolter et al. 2010; Büntgen et al. 2007; Dittmar and Elling 1999; Mäkinen et al. 2002; Neuwirth et al. 2004).

For fir above $900 \mathrm{~m}$ a.s.l., we found a significant positive effect of above-average temperatures from January till March on growth (Fig. S1). As warming in winter can initiate winter photosynthesis in fir (Guehl 1985), this could improve carbohydrate storage and growth in the following growing season (Lebourgeois 2007). Besides, higher temperatures in spring allow an early start of cambial activity (Deslauriers et al. 2008; Kozlowski and Pallardy 1997; Rossi et al. 2007) thereby advancing tree-ring development. Positive correlations with precipitation in February for lowaltitude sites might point at a favorable effect of aboveaverage winter temperatures on growth as well, as high precipitation amounts in winter are often associated with relatively warm air (low-pressure area). Also for other regions, positive effects of winter temperature on fir growth have been reported (e.g. Bouriaud and Popa 2009; Frank and Esper 2005; Lebourgeois et al. 2010; Rolland et al. 1999).
In our study, we did not observe a consistent correlation between water availability in summer and radial growth of high-elevation fir, whereas previous studies in the Black Forest found close relations with the climatic water balance during the growing season (e.g. Kahle 1996; Spiecker 1991a,b). Especially in the dry year 1976, growth of highaltitude fir was strongly reduced (Spiecker 1991b). Probably, this growth reduction relates to preconditioning of tree vigor. Pichler and Oberhuber (2007) reported that droughtexposed forest trees react less sensitive when a dry year is preceded by sufficiently wet years. In contrast to 2003, a year in which the growth of high-altitude fir was much less reduced compared to spruce and low-altitude fir, the year 1976 was preceded by several dry years. Hence, it is likely that this preconditioning in 1976 has negatively affected growth of these trees (cf. Becker 1989). In Bavaria, sulphur dioxide $\left(\mathrm{SO}_{2}\right)$ emissions were further suggested as an important influencing factor for the observed growth depression of fir (Elling et al. 2009). For the Black Forest, possible effects of $\mathrm{SO}_{2}$ are less likely as concentrations were (and are) much lower compared to those observed in Bavaria (Beilke and Uhse 1999). A moderate drought sensitivity of fir is as well found in dendroecological studies in other regions (e.g. Bouriaud and Popa 2009; Zang et al. 2011).

Although numerous studies along altitudinal gradients report positive effects of summer temperature on tree growth at high elevation (e.g. Dittmar and Elling 1999; Frank and Esper 2005; Leal et al. 2007; Savva et al. 2006), this was not consistent with our study. It may be suggested that our highelevation sample sites are not as close to the upper tree line as sites in these other studies. This is in accordance with the observation of Fritts et al. (1965) that climatic control of growth increases towards the limits of tree growth. Trees growing on more favorable sites do not respond as strongly to temperature as trees on temperature-limited sites (e.g. Čejkova and Kolář 2009; Wilson and Hopfmüller 2001).

Further, trees at high elevation are generally not waterlimited, but when temperatures are high, the importance of water availability increases here as well (e.g. Carrer et al. 1998; Tranquillini 1964). In the northeastern Italian Alps, Anfodillo et al. (1998) demonstrated for three coniferous species that even moderate changes in water deficit might reduce transpiration in trees adapted to moist conditions. Norway spruce and Stone pine (Pinus cembra L.) were found more susceptible for water shortage than the deep rooting European larch (Larix decidua Mill.). On longterm forest research plots in Switzerland, Zingg and Bürgi (2008) observed a higher drought susceptibility of spruce compared to fir. Fir has, like larch, a deep taproot that allows reaching deeper water reserves, whereas spruce typically develops a superficial root system (Larcher 1995). Therefore, growth of spruce may be more negatively affected when an increase in temperatures is not followed by an 
increase in water supply. In the Swiss Alps, late-summer drought stress of subalpine spruce has already increased since $\sim 1900$ following the recent warming trend (Büntgen et al. 2006).

\section{Conclusion}

We observed differences in growth patterns and climate response of silver fir and Norway spruce at southwestexposed sites along an altitudinal gradient in the Black Forest. Overall, we indentified water availability as a major growth-limiting factor for fir at low altitudes and spruce along our altitudinal gradient. In a future warmer climate with more frequent and severe summer droughts (Beniston 2004) growth and vitality, especially of spruce, will be at risk, when an increased evaporative demand cannot be compensated by water supply. As an adaptation measure, forest conversion has to be considered (cf. Baumgarten et al. 2005). However, uncertainty remains on future growth responses of both species, as climate change may subject these trees to extreme climatic conditions they were not exposed to before.

Acknowledgements The authors wish to thank Gregor Seitz and the Forest Districts Breisgau-Hochschwarzwald, Lörrach, Waldshut and Stadtwald Freiburg for their support during the tree sampling. Felix Baab and Clemens Koch are thanked for their technical assistance in the lab. Comments of Heinrich Spiecker, David Frank, two anonymous reviewers and the subject editor Erwin Dreyer helped on improving earlier versions of this manuscript.

Funding MMT received a PhD scholarship of the Landesgraduiertenförderung Baden-Württemberg. EM was financially supported by the EU-FP7 project MOTIVE ('Models for adaptive management', grant no. 226544).

\section{References}

Affolter P, Büntgen U, Esper J, Rigling A, Weber P, Luterbacher J, Frank D (2010) Inner Alpine conifer response to 20th century drought swings. Eur J For Res 129:289-298

Anfodillo T, Rento S, Carraro V, Furlanetto L, Urbinati C, Carrer M (1998) Tree water relations and climatic variations at the alpine timberline: seasonal changes of sap flux and xylem water potential in Larix decidua Miller, Picea abies (L.) Karst., and Pinus cembra L. Ann For Sci 55:159-172

Baumgarten M, Kayser J, Michiels H-G, von Teuffel K (2005) Umbaubedarf in Fichtenwäldern Baden-Württembergs. In: von Teuffel K, Baumgarten M, Hanewinkel M et al (eds) Waldumbau für eine zukunftsorientierte Waldwirtschaft: Ergebnisse aus dem Südschwarzwald. Springer, Berlin

Becker M (1989) The role of climate on present and past vitality of silver fir forests in the Vosges mountains of northeastern France. Can J For Res 19:1110-1117

Beilke S, Uhse K (1999) Jahresbericht 1998 aus dem Messnetz des Umweltbundesamtes. http://www.umweltdaten.de/publikationen/ fpdf-1/3279.pdf (accessed on 12-06-2012)
Beniston M (2004) The 2003 heat wave in Europe: a shape of things to come? An analysis based on Swiss climatological data and model simulations. Geophys Res Lett 31:2022-2026

Biondi F, Waikul K (2004) DENDROCLIM2002: A C++ program for statistical calibration of climate signals in tree-ring chronologies. Comput Geosci 30:303-311

Bouriaud O, Popa I (2009) Comparative dendroclimatic study of Scots pine, Norway spruce, and silver fir in the Vrancea Range, Eastern Carpathian Mountains. Trees 23:95-106

Büntgen U, Frank DC, Schmidhalter M, Neuwirth B, Seifert M, Esper $\mathrm{J}$ (2006) Growth/climate response shift in a long subalpine spruce chronology. Trees 20:99-110

Büntgen U, Frank DC, Kaczka RJ, Verstege A, Zwijacz-Kozica T, Esper J (2007) Growth responses to climate in a multi-species tree-ring network in the Western Carpathian Tatra Mountains, Poland and Slovakia. Tree Physiol 27:689-702

Carrer M, Urbinati C (2004) Age-dependent tree-ring growth responses to climate in Larix decidua and Pinus cembra. Ecology 85:730-740

Carrer M, Anfodillo T, Urbinati C, Carraro V (1998) High altitude forest sensitivity to global warming: results from long-term and short-term analyses in the Eastern Italian Alps. In: Beniston M, Innes JL (eds) The impacts of climate variability on forests, Lecture NOTES in earth sciences, 74. Springer, Berlin, pp 171189

Čejkova A, Kolář T (2009) Extreme radial growth reactions of Norway spruce along an altitudinal gradient in the Sumava mountains. Geochronometria 33:41-47

Christensen JH, Hewitson B, Busuoic A, Chen A, Gao X, Held R, Jones R, Kolli RK, Kwon W-T, Laprise R, Magana Rueda V, Mearns L, Menéndez CG, Räisänen J, Rinke A, Sarr A, Whetton P (2007) Regional climate projections. In: Solomon S, Qin D, Manning M et al (eds) Climate Change 2007: the physical science basis. Contribution of Working Group I to the Fourth Assessment Report of the Intergovernmental Panel on Climate Change. Cambridge University Press, Cambridge

Ciais P, Reichstein M, Viovy N, Granier A, Ogee J, Allard V, Aubinet M, Buchmann N, Bernhofer C, Carrara A, Chevallier F, De Noblet N, Friend AD, Friedlingstein P, Grunwald T, Heinesch B, Keronen P, Knohl A, Krinner G, Loustau D, Manca G, Matteucci G, Miglietta F, Ourcival JM, Papale D, Pilegaard K, Rambal S, Seufert G, Soussana JF, Sanz MJ, Schulze ED, Vesala T, Valentini R (2005) Europe-wide reduction in primary productivity caused by the heat and drought in 2003. Nature 437:529-533

Cook ER, Peters K (1981) The smoothing spline: a new approach to standardizing forest interior tree-ring width series for dendroclimatic studies. Tree-Ring Bull 41:45-53

Deslauriers A, Rossi S, Anfodillo T, Saracino A (2008) Cambial phenology, wood formation and temperature thresholds in two contrasting years at high altitude in southern Italy. Tree Physiol 28:863-871

Desplanque C, Rolland C, Schweingruber FH (1999) Influence of species and abiotic factors on extreme tree ring modulation: Picea abies and Abies alba in Tarentaise and Maurienne (French Alps). Trees 13:218-227

Dittmar C, Elling W (1999) Radial growth of Norway spruce and European beech in relation to weather and altitude. Forstwiss Centralbl 118:251-270

Elling W, Dittmar C, Pfaffelmoser K, Rötzer T (2009) Dendroecological assessment of the complex causes of decline and recovery of silver fir (Abies alba Mill.) in Southern Germany. For Ecol Manage 257:1175-1187

Frank D, Esper J (2005) Characterization and climate response patterns of a high-elevation, multi-species tree-ring network in the European Alps. Dendrochronologia 22:107-121

Fritts HC (1976) Tree rings and climate. Academic, London, p 567 
Fritts HC, Smith DG, Cardis JW, Budelsky CA (1965) Tree-ring characteristics along a vegetation gradient in Northern Arizona. Ecology 46:394-401

Gerecke K-L (1986) Zuwachsuntersuchungen an vorherrschenden Tannen aus Baden-Württemberg. AFJZ 157:59-68

Graumlich LJ (1993) Response of tree growth to climatic variation in the mixed conifer and deciduous forests of the upper Great Lakes region. Can J For Res 23:133-143

Guehl JM (1985) Etude comparée des potentialités hivernales d'assimilation carbonée de trois conifères de la zone tempérée (Pseudotsuga menziesii Mirb., Abies alba Mill. et Picea excelsa Link.). Ann For Sci 42:23-38

Jolly WM, Dobbertin M, Zimmermann NE, Reichstein M (2005) Divergent vegetation growth responses to the 2003 heat wave in the Swiss Alps. Geophys Res Lett 32:1-4

Kahle HP (1994) Modellierung der Zusammenhänge zwischen der Variation von klimatischen Elementen des Wasserhaushalts und dem Radialzuwachs von Fichten (Picea abies (L.) Karst.) aus Hochlagen des Südschwarzwaldes: Eine standortbezogene dendroökologische Untersuchung unter besonderer Berücksichtigung von Trockenstress. Dissertation, Albert-Ludwigs-University Freiburg

Kahle HP (1996) Modelling the dynamics of growth-climate relationships of Norway spruce and silver fir in high elevations of the Black Forest. In: Proceedings IUFRO Conference. Berggießhübel near Dresden, pp 93-103

Kienast F, Schweingruber FH, Bräker O, Schär E (1987) Tree-ring studies on conifers along ecological gradients and the potential of single-year analysis. Can J For Res 17:683-696

Körner C, Paulsen J (2004) A world-wide study of high altitude treeline temperatures. J Biogeogr 31:713-732

Kozlowski T, Pallardy S (1997) Growth control in woody plants. Academic, San Diego, p 641

Larcher W (1995) Physiological plant ecology. Springer, Berlin, p 513

Leal S, Melvin TM, Grabner M, Wimmer R, Briffa KR (2007) Tree-ring growth variability in the Austrian Alps: the influence of site, altitude, tree species and climate. Boreas 36:426-440

Lebourgeois F (2007) Climatic signal in annual growth variation of silver fir (Abies alba Mill.) and spruce (Picea abies Karst.) from the French Permanent Plot Network (RENECOFOR). Ann For Sci 64:333-343

Lebourgeois F, Rathgeber CBK, Ulrich E (2010) Sensitivity of French temperate coniferous forests to climate variability and extreme events (Abies alba, Picea abies and Pinus sylvestris). J Veg Sci 21:364-376

Lingg W (1986) Dendroökologische Studien an Nadelbäumen im alpinen Trockental Wallis (Schweiz). Berichte/Eidgenössische Anstalt für das Forstliche Versuchswesen, vol 287

Mäkinen H, Nöjd P, Kahle HP, Neumann U, Tveite B, Mielikäinen K, Röhle H, Spiecker H (2002) Radial growth variation of Norway spruce (Picea abies (L.) Karst.) across latitudinal and altitudinal gradients in central and northern Europe. For Ecol Manage 171:243-259

Maracchi G, Sirotenko O, Bindi M (2005) Impacts of present and future climate variability on agriculture and forestry in the temperate regions: Europe. In: Salinger J, Sivakumar MVK, Motha RP (eds) Increasing climate variability and change. Springer, Netherlands, pp $117-135$

Meining S, Schröter H, von Wilpert K (2004) Waldzustandsbericht 2004 der Forstlichen Versuchs- und Forschungsanstalt BadenWürttemberg. FVA, Freiburg

Mérian P, Lebourgeois F (2011) Consequences of decreasing the number of cored trees per plot on chronology statistics and climategrowth relationships: a multispecies analysis in a temperate climate. Can J For Res 41:2413-2422
Neumann U, Röhle H (2001) The weather-dependent annual radial increment of Norway Spruce (Picea abies (L.) Karst.) in mountainous regions of Saxony. Forstwiss Centralbl 120:277-287

Neuwirth B, Esper J, Schweingruber FH, Winiger M (2004) Site ecological differences to the climatic forcing of spruce pointer years from the Lötschental, Switzerland. Dendrochronologia 21:69-78

Palmer W (1965) Meteorological drought. Office of Climatology, US Weather Bureau, Washington, DC, Weather bureau paper, vol 45, $58 \mathrm{pp}$

Pichler P, Oberhuber W (2007) Radial growth response of coniferous forest trees in an inner Alpine environment to heat-wave in 2003. For Ecol Manage 242:688-699

Rolland C, Michalet R, Desplanque C, Petetin A, Aime S (1999) Ecological requirements of Abies alba in the French Alps derived from dendro-ecological analysis. J Veg Sci 10:297-306

Rolland C, Desplanque C, Michalet R, Schweingruber FH (2000) Extreme tree rings in spruce (Picea abies (L.) Karst.) and fir (Abies alba Mill.) stands in relation to climate, site, and space in the southern French and Italian Alps. Arct Antarct Alp Res 32:1-13

Rossi S, Deslauriers A, Anfodillo T, Carraro V (2007) Evidence of threshold temperatures for xylogenesis in conifers at high altitudes. Oecologia 152:1-12

Savva Y, Oleksyn J, Reich PB, Tjoelker MG, Vaganov EA, Modrzynski J (2006) Interannual growth response of Norway spruce to climate along an altitudinal gradient in the Tatra Mountains, Poland. Trees 20:735-746

Scharnweber T, Manthey M, Criegee C, Bauwe A, Schröder C, Wilmking M (2011) Drought matters - declining precipitation influences growth of Fagus sylvatica L. and Quercus robur L. in north-eastern Germany. For Ecol Manage 262:947-961

Schlenker G, Müller S (1978) Erläuterungen zur Karte der Regionalen Gliederung von Baden-Württemberg III. Teil (Wuchsgebiet Schwarzwald). Mitteilungen des Vereins für Forstliche Standortskunde und Forstpflanzenzüchtung Nr. 26

Spiecker H (1991a) Growth variation and environmental stresses: longterm observations on permanent research plots in southwestern Germany. Water Air Soil Pollut 54:247-256

Spiecker H (1991b) Zur Dynamik des Wachstums von Tannen und Fichten auf Plenterwald-Versuchsflaechen im Schwarzwald. AFZ 46:1076-1080

Szeicz JM, MacDonald GM (1994) Age-dependent tree-ring growth responses of sub-arctic white spruce to climate. Can J For Res 24:120-132

Tranquillini W (1964) The physiology of plants at high altitudes. Annu Rev Plant Physiol 15:345-362

Tranquillini W (1979) Physiological ecology of the alpine timberline. Tree existence in high altitudes with special reference to the European Alps, vol 31. Ecological studies. Springer, Berlin, 137

van der Maaten-Theunissen M, Bouriaud O (2012) Climate-growth relationships at different stem heights in silver fir and Norway spruce. Can J For Res 42:958-969

Wells N, Goddard S, Hayes MJ (2004) A self-calibrating Palmer drought severity index. J Climate 17:2335-2351

Wigley TML, Briffa KR, Jones PD (1984) On the average value of correlated time-series, with applications in dendroclimatology and hydrometeorology. J Clim Appl Meteorol 23:201-213

Wilson RJS, Hopfmüller M (2001) Dendrochronological investigations of Norway spruce along an elevational transect in the Bavarian Forest, Germany. Dendrochronologia 19:67-69

Zang C, Rothe A, Weis W, Pretzsch H (2011) Zur Baumarteneignung bei Klimawandel: Ableitung der Trockenstress-Anfälligkeit wichtiger Waldbaumarten aus Jahrringbreiten. AFJZ 182:98-112

Zingg A, Bürgi A (2008) Drought periods since 1900 and growth of forest stands: an analysis of long-term data series. Schweiz Z Forstwes 159:352-361 